\title{
Physiological Role of Glutaminase Activity in Saccharomyces cerevisiae
}

\author{
By MARIO SOBERÓN AND ALICIA GONZÁLEZ* \\ Centro de Investigación sobre Fijación de Nitrógeno, UNAM, Apartado Postal 565-A, \\ Cuernavaca, Morelos, Mexico
}

(Received 2 April 1986; revised 30 June 1986)

\begin{abstract}
The participation of glutaminase activity in glutamine degradation was studied in a wild-type strain (S288C) of Saccharomyces cerevisiae. Evidence is presented that this strain has two glutaminase activities, a readily extractable form (glutaminase B) and a membrane-bound enzyme (glutaminase A). Glutaminase A and B activities could also be distinguished by their thermostability, pyruvate sensitivity and $\mathrm{pH}$ optimum. Glutaminase B activity was negatively modulated by some 2-oxo acids, and in vivo pyruvate accumulation inhibited this activity. A mutant strain (CN10) with an altered glutaminase B activity was isolated and partially characterized. Its glutaminase B activity was more sensitive to inhibition by pyruvate and 2oxoglutarate than the wild type, thus resulting in inactivation of this enzyme in vivo. The physiological role of glutaminase activity is discussed with regard to the phenotype shown by the mutant strain.
\end{abstract}

\section{INTRODUCTION}

Glutamine plays a key role in nitrogen metabolism; it supplies the nitrogen required for the biosynthesis of a variety of metabolic intermediates, and has also been proposed to be the corepressor of nitrogen catabolite repression in Saccharomyces cerevisiae (Dubois et al., 1977; Legrain et al., 1982). Due to the dual role that glutamine plays in cellular metabolism, as both a precursor of nitrogenous compounds and a modulator of nitrogen metabolism, its biosynthesis and degradation must be highly regulated in order to maintain an intracellular concentration that will support biosynthetic needs without resulting in a repressive effect.

Glutaminase (EC 3.5.1.2.) catalyses the hydrolysis of L-glutamine for form L-glutamate and ammonium ions. Two major forms of glutaminase, a readily extractable form and a membranebound enzyme, have been found in pig brain mitochondria (Nimmo \& Tipton, 1978). Previous studies have also shown the existence of two glutaminases in Escherichia coli and Bacillus licheniformis (Cook et al., 1981; Hartman, 1968); however, the physiological role of these enzymes has not been analysed in these micro-organisms. The existence of a glutaminase in $S$. cerevisiae has also been described (Averman et al., 1981). Here we present evidence that there are two glutaminases in $S$. cerevisiae and that these enzymes have different cellular locations. We also describe the isolation and characterization of a mutant altered in one of the two glutaminases.

\section{METHODS}

$S$. cerevisiae strains. These came from the Cold Spring Harbor Laboratory, New York, USA. They were: the wild-type strain S288C (Mata mall gal2), strain AH22 (MATa;leu2-3;leu2-112; his3; canl) and strain D286-A (MATa ; adel; hisl).

Growth conditions. Strains were routinely grown on minimal medium (MM) containing salts, trace elements and vitamins following the formula of Difco Yeast Nitrogen Base, plus $0.01 \%(\mathrm{w} / \mathrm{v})$ amino acid as required. Glucose $(2 \%, \mathrm{w} / \mathrm{v})$ was used as carbon source and $40 \mathrm{~mm}-\left(\mathrm{NH}_{4}\right)_{2} \mathrm{SO}_{4}$ and/or $0 \cdot 1 \%(\mathrm{w} / \mathrm{v})$ glutamine as nitrogen source. Cells were incubated at $30^{\circ} \mathrm{C}$ with agitation (175 r.p.m.) unless otherwise stated. Growth was followed by measuring optical density at $650 \mathrm{~nm}$.

Abbreviation: MM, minimal medium. 
Mutagenesis and mutant selection. To obtain mutants unable to use glutamine as nitrogen source, strain S288C was mutagenized by treatment with ethylmethane sulphonate (EMS), following the method of Fink (1970). After mutagenesis, the cells were allowed a period of growth on $\mathrm{MM}$ containing $\left(\mathrm{NH}_{4}\right)_{2} \mathrm{SO}_{4}$ as nitrogen source. Cells that could not use glutamine as nitrogen source were selected by using the antibiotic $N$-glycosyl-polyfungin (Polaina \& Conde, 1981). Cells were spread on MM plates with $\left(\mathrm{NH}_{4}\right)_{2} \mathrm{SO}_{4}$ as nitrogen source and incubated at $30{ }^{\circ} \mathrm{C}$. Colonies which appeared after 3-5 d were replica plated to $\mathrm{MM}$ plates containing $\left(\mathrm{NH}_{4}\right)_{2} \mathrm{SO}_{4}$ or glutamine as nitrogen source. Cells which failed to grow on glutamine as nitrogen source were purified and further characterized.

Determination of pyruvate. For the estimation of pyruvate, extracts were prepared as described by Kang et al. (1982). The concentration of pyruvate was determined with beef lactate dehydrogenase, by following NADH oxidation at $340 \mathrm{~nm}$ (Bergmeyer, 1963).

Extraction and determination of amino acid pools. The procedures were as described by González et al. (1985).

In vitro determination of glutaminase. Soluble extracts were prepared by grinding whole cells in $50 \mathrm{~mm}-\mathrm{Tris} / \mathrm{HCl}$ buffer at the appropriate $\mathrm{pH}$, using a Braun homogenizer and glass beads. The extracts were centrifuged for $20 \mathrm{~min}$ at $9000 \mathrm{~g}$, and the supernatant was desalted on a Sephadex G-25 column equilibrated and eluted with the extraction buffer. When glutaminase activity was assayed in pellets, these were solubilized with the extraction buffer containing $0 \cdot 1 \%(\mathrm{w} / \mathrm{v})$ Triton X-100 and centrifuged for $20 \mathrm{~min}$ at $9000 \mathrm{~g}$; the supernatant was used as the source of enzyme.

The activity was assayed in a $0.5 \mathrm{ml}$ reaction mixture containing $50 \mathrm{~mm}$-Tris/ $\mathrm{HCl}$ at the appropriate $\mathrm{pH}, 60 \mathrm{~mm}$ [U- ${ }^{14} \mathrm{C}$ ]glutamine $0 \cdot 0045 \mu \mathrm{Ci} \mathrm{nmol}-1,0.167 \mathrm{kBq} \mathrm{mol}^{-1}$ ) and $0 \cdot 1 \mathrm{ml}$ cell extract. The reaction mixture was incubated at $37^{\circ} \mathrm{C}$ for $50 \mathrm{~min}$ and then stopped by addition of $3 \mathrm{ml}$ cold $80 \%(\mathrm{v} / \mathrm{v})$ ethanol. This was lyophilized and the residue was resuspended in $3 \%(\mathrm{w} / \mathrm{v}) \mathrm{HClO}_{4}$, spotted on Whatman $3 \mathrm{MM}$ filter paper, and chromatographed using $\mathrm{n}$-butanol/acetic acid/water $(6: 1: 4$, by vol.). Unlabelled amino acid standards were run in parallel and stained with ninhydrin $(1 \%, w / v$, in ethanol), and the radioactivity of $[\mathrm{U}-14 \mathrm{C}]$ glutamate was estimated. In the experiments on glutaminase inhibition by 2-oxo acids the reaction mixtures were incubated for $10 \mathrm{~min}$ at $37^{\circ} \mathrm{C}$ with the 2 -oxo acids before the reaction was started with $\left[\mathrm{U}-{ }^{14} \mathrm{C}\right]$ glutamine. Units of activity (U) are nmol glutamate produced $\mathrm{min}^{-1}$

In vivo determination of glutaminase. In vivo glutaminase activity was measured by following glutamate production from a previously labelled intracellular pool of glutamine in cells grown on glutamine as the sole nitrogen source until they reached an $\mathrm{OD}_{650} \quad 0 \cdot 4$. Cells were harvested by filtration and concentrated tenfold in MM with $0.5 \mathrm{mM}-\left[\mathrm{U}^{-14} \mathrm{C}\right] \mathrm{glutamine}\left(4.5 \mu \mathrm{Ci} \mathrm{nmol}^{-1}, 166.5 \mathrm{kBq} \mathrm{nmol}^{-1}\right)$ and $25 \mathrm{~mm}$-oxamic acid in order to avoid glutamine degradation by transamination (Calderón et al., 1985) (cells of mutant CN10 were concentrated as much as necessary to reach the same $\mathrm{OD}_{650}$ as the wild-type strain). The cell mixture was incubated for $5 \mathrm{~min}$ at $30{ }^{\circ} \mathrm{C}$ to allow [U-14 $\mathrm{C}$ ]glutamine uptake and then labelled glutamine was removed by filtration and the cells were washed with $0.5 \mathrm{~mm}$-unlabelled glutamine. Part of the cell mixture was removed to determine the intracellular pool of glutamine $(a)$, and the amount of radioactivity in the glutamine $(b)$ and glutamate $(c)$ pools as described above.

Glutamate production from the intracellular pool of glutamine was followed in the rest of the cell mixture resuspended in MM with $25 \mathrm{~mm}$-oxamic acid without exogenous glutamine. After incubation for $5 \mathrm{~min}$ at $30^{\circ} \mathrm{C}$, the cells were harvested by filtration and the reaction was stopped by heating the cells, resuspended in $80 \%(\mathrm{v} / \mathrm{v})$ ethanol, for $10 \mathrm{~min}$ in boiling water; debris was removed by filtration through $0.22 \mu \mathrm{m}$ Millipore filters. The filtrates were lyophilized and the amount of radioactivity in the glutamate pool $(d)$ was determined as described above.

In order to present the data as nmol glutamate formed $\mathrm{min}^{-1}$, we assumed that the intracellular pool of glutamine was homogeneously labelled and calculated the amount of radioactivity which corresponded to $1 \mathrm{nmol}$ glutamine as $a / b$ (see above). The amount of glutamate formed was calculated from the incorporation of radioactivity into the glutamate pool ( $d-c$ : see above).

Protein determination. This was done by the Lowry method using bovine serum albumin as standard.

Chemicals. All amino acids, EMS, oxamic acid and bovine serum albumin were obtained from Sigma. Triton X100 was obtained from Bio-Rad. [U- ${ }^{14}$ C]glutamine was from New England Nuclear. $N$-Glycosyl-polyfungin was a kind gift from Dr Norman J. Pieniazek (Department of Genetics, University of Warsaw, Poland).

\section{RESULTS}

Isolation and characterization of a mutant impaired in glutamine utilization

A mutant unable to grow on glutamine as sole nitrogen source was isolated from the wild-type strain S288C, as described in Methods. This mutant (CN10) was unable to grow on glutamine even in the presence of ammonium (Fig. $1 a, b$ ), and its doubling time on ammonium as nitrogen source was three times that of the wild-type strain grown under the same conditions (Fig. 1c). 


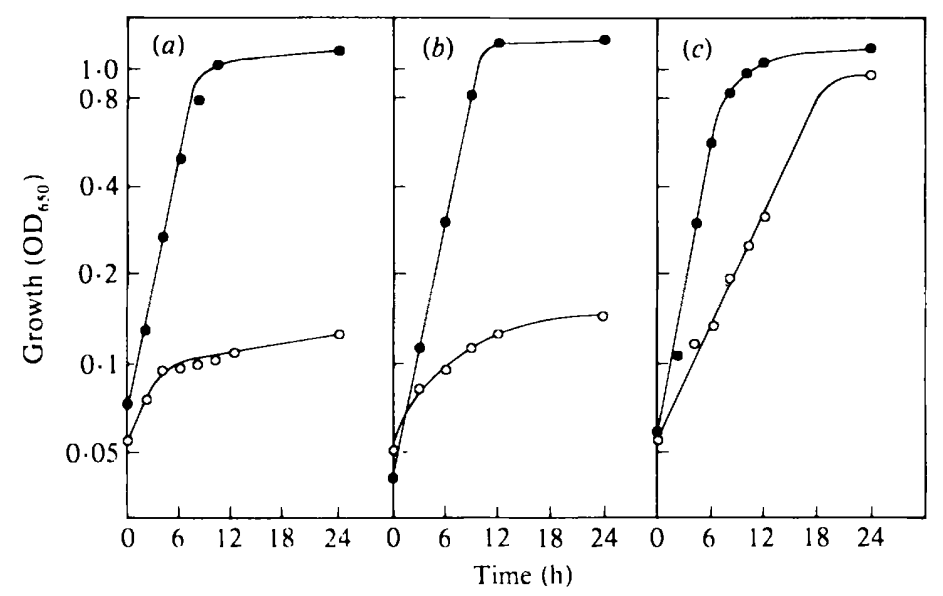

Fig. 1. Growth of the wild-type strain S288C (O) and the mutant $\mathrm{CN} 10(\mathrm{O})$ on different nitrogen sources: $(a) 0.1 \%(\mathrm{w} / \mathrm{v})$ glutamine; $(b) 0.1 \%(\mathrm{w} / \mathrm{v})$ glutamine plus $40 \mathrm{mM}^{-}\left(\mathrm{NH}_{4}\right)_{2} \mathrm{SO}_{4} ;(c) 40 \mathrm{mM}-$ $\left(\mathrm{NH}_{4}\right)_{2} \mathrm{SO}_{4}$.

Table 1. Glutaminase $A$ and $B$ activities in extracts of strain S288C and mutant CN10

Cells were grown for $12 \mathrm{~h}$ on $\mathrm{MM}$ with $0 \cdot 1 \%(\mathrm{w} / \mathrm{v})$ glutamine as nitrogen source.

\begin{tabular}{|c|c|c|c|c|}
\hline \multirow[b]{2}{*}{ Strain } & \multicolumn{2}{|c|}{$\begin{array}{l}\text { Glutaminase } A(\mathrm{pH} 7.5) \\
{\left[\mathrm{U}(\mathrm{mg} \text { protein })^{-1}\right]}\end{array}$} & \multicolumn{2}{|c|}{$\begin{array}{l}\text { Glutaminase B }(\mathrm{pH} 8 \cdot 1) \\
{\left[\mathrm{U}(\mathrm{mg} \text { protein })^{-1}\right]}\end{array}$} \\
\hline & Desalted & Non-desalted & Desalted & Non-desalted \\
\hline & 39. & 30 & 29 & 17. \\
\hline $\mathrm{CN}$ & 36.60 & $25 \cdot 38$ & $28 \cdot 50$ & $10 \cdot 36$ \\
\hline
\end{tabular}

Mutant CN10 was mated with strains AH22 and D286-A. The diploids obtained were able to grow on glutamine as nitrogen source, showing that the mutation in $\mathrm{CN} 10$ was recessive. However, these diploids sporulated poorly and formed large aberrant cells. Some of the diploids which sporulated gave no viable spores. Since it has been proposed that in $S$. cerevisiae, glutamine catabolism proceeds mainly by a glutaminase (Averman et al., 1981), we measured this activity for cells incubated on glutamine as sole nitrogen source to test whether mutant CN10 was altered in this enzyme : the mutant had only $16 \%$ of the activity found in the wild-type strain. Nevertheless it is possible that this assay also determined the activity of other enzymes that degrade glutamine to glutamate.

When glutaminase activity was measured in vitro, two $\mathrm{pH}$ optima were apparent: 7.5 and 8.1 (data not shown). We have named these two activities glutaminase A and B, respectively. Glutaminase activity was assayed at the two $\mathrm{pH}$ optima in extracts obtained from the mutant and wild-type strains incubated on glutamine as nitrogen source (Table 1). In desalted extracts, glutaminase A and B activities were similar in the two strains. Comparing the activity of glutaminase $\mathrm{A}$ in extracts obtained from the wild-type strain and mutant $\mathrm{CN} 10$, it can be seen that desalted extracts showed an increase in activity corresponding in the first case to $28 \%$ of that found in non-desalted extracts, and in the latter case to $44 \%$. However, in the case of glutaminase B, desalted extracts from the wild-type strain and mutant CN10 showed increases of $70 \%$ and $175 \%$, respectively, when compared to the values obtained in non-desalted extracts (Table 1). This suggested that the activity of glutaminase B was negatively modulated by an inhibitor present in the extracts and that this effect was stronger in extracts obtained from mutant CN10. This could mean that the mutation in $\mathrm{CN} 10$ had rendered this enzyme more sensitive to these effectors, or that CN10 accumulated more of these inhibitor molecules. 


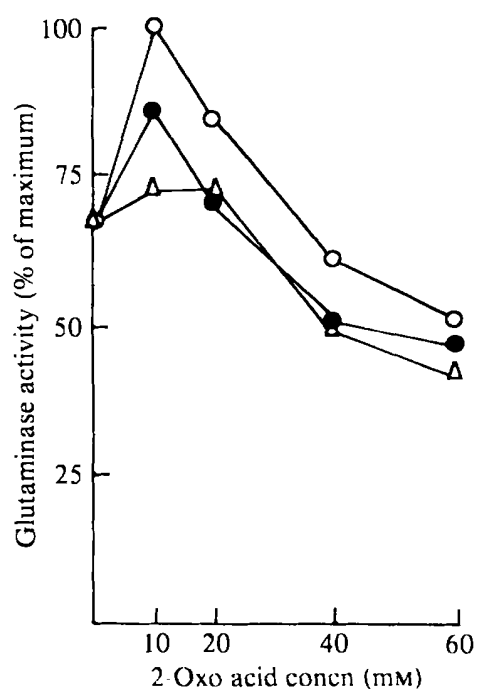

Fig. 2. Inhibition of glutaminase $B$ by 2 -oxo acids: $\bigcirc$, pyruvate; $P$, glyoxylate, $\triangle, 2$-oxoglutarate. The activity corresponding to $100 \%$ was $52.23 \mathrm{U}$ (mg protein) $)^{-1}$.

Table 2. Glutaminase B activity assayed in the presence of different 2-oxo acids in extracts of strain $S 288 C$ and mutant CN10

Cells were grown for $12 \mathrm{~h}$ on $\mathrm{MM}$ with $0.1 \%(\mathrm{w} / \mathrm{v})$ glutamine as nitrogen source; $0.1 \mathrm{mg}$ protein was used in each assay.

\begin{tabular}{|c|c|c|c|c|c|c|}
\hline \multirow{3}{*}{$\begin{array}{l}\text { Strain } \\
\text { S288C }\end{array}$} & \multirow{2}{*}{$\begin{array}{l}\text { 2-Oxo acid } \\
(40 \mathrm{mM})\end{array}$} & \multicolumn{5}{|c|}{$\begin{array}{c}\text { Glutaminase B activity (pH } 8 \cdot 1) \\
{\left[\mathrm{U} \mathrm{m} l^{-1}: \% \text { inhibition in parentheses] }\right.}\end{array}$} \\
\hline & & 2-Oxoglutarate & Pyi & Ivate & Gly & xylate \\
\hline & $237 \cdot 4$ & $174.08 \quad(26.6 \%)$ & $214 \cdot 12$ & $(9.8 \%$ & 175 & $\left(25.9^{\circ}\right)$ \\
\hline CN10 & $290 \cdot 12$ & $159.80 \quad(44.9 \%)$ & $228 \cdot 08$ & $(21.3 \%)$ & 227.84 & $(21.4 \%)$ \\
\hline
\end{tabular}

In the experiments described below, we studied the regulation of glutaminases $\mathrm{A}$ and $\mathrm{B}$, in order to determine if both activities were regulated by the same effectors, or whether the effect of dialysis on glutaminase A could be explained by assuming that a fraction of glutaminase B was being extracted at $\mathrm{pH} 7 \cdot 5$.

\section{2-Oxo acids regulate glutaminase $B$ activity}

Glutaminase B activity was inhibited by pyruvate, 2-oxoglutarate and glyoxylate in extracts obtained from the wild-type strain, but with low concentrations of inhibitor the enzyme activity was increased (Fig. 2). Such behaviour has been found in other enzymes which are subject to allosteric regulation (Monod et al., 1965). Since we found a greater effect of dialysis in extracts obtained from the mutant CN10 than in those from the wild-type, we decided to determine whether the enzyme from this source was more sensitive to inhibition by 2-oxo acids. 2Oxoglutarate and pyruvate had a greater effect on the enzyme obtained from the mutant strain, but the inhibition by glyoxylate was similar for extracts from both strains (Table 2).

These data suggested that the increase in glutaminase B activity detected in desalted versus non-desalted extracts in the wild-type and mutant strains might be attributable to the presence of these 2-oxo acids in undialysed extracts, and that the mutation present in mutant CN10 had probably increased its sensitivity towards these compounds. 
Table 3. Intracellular pools of pyruvate and glutaminase B activity of strain S288C grown statically (microaerophilic conditions) or with agitation

Cells were grown on $\mathrm{MM}$ with $0.1 \%(\mathrm{w} / \mathrm{v})$ glutamine as nitrogen source.

\begin{tabular}{|c|c|c|c|}
\hline \multirow[b]{2}{*}{ Conditions } & \multirow[b]{2}{*}{$\begin{array}{c}\text { Pyruvate } \\
{\left[\mathrm{nmol}(\mathrm{mg} \text { protein })^{-1}\right]}\end{array}$} & \multicolumn{2}{|c|}{$\begin{array}{l}\text { Glutaminase B activity } \\
{\left[\mathrm{U}(\mathrm{mg} \text { protein })^{-1}\right]}\end{array}$} \\
\hline & & in vivo & in vitro $(\mathrm{pH} 8.1)$ \\
\hline $\begin{array}{l}\text { Agitated* } \\
\text { Static }\end{array}$ & $\begin{array}{l}132.9 \\
293.6\end{array}$ & $\begin{array}{l}62 \cdot 17 \\
\text { ND }\end{array}$ & $\begin{array}{r}16.49 \\
5.86\end{array}$ \\
\hline Mixed extracts & - & - & $4 \cdot 48+$ \\
\hline
\end{tabular}

Table 4. Intracellular pools of glutamine and glutamate in strain S288C and mutant CN10

Cells were grown on $\mathrm{MM}$ for $12 \mathrm{~h}$ with $0.1 \%(\mathrm{w} / \mathrm{v})$ glutamine and/or $40 \mathrm{mM}-\left(\mathrm{NH}_{4}\right)_{2} \mathrm{SO}_{4}$ as nitrogen source.

\begin{tabular}{|c|c|c|c|c|}
\hline \multirow[b]{2}{*}{ Nitrogen source } & \multicolumn{2}{|c|}{$\begin{array}{c}\text { Glutamine } \\
{\left[\mu \mathrm{mol}(\mathrm{mg} \text { protein })^{-1}\right]}\end{array}$} & \multicolumn{2}{|c|}{$\begin{array}{c}\text { Glutamate } \\
{\left[\mu \mathrm{mol}(\mathrm{mg} \text { protein })^{-1}\right]}\end{array}$} \\
\hline & S288C & $\mathrm{CN} 10$ & S288C & $\mathrm{CN} 10$ \\
\hline $\begin{array}{l}\text { Glutamine } \\
\text { Glutamine }+\left(\mathrm{NH}_{4}\right)_{2} \mathrm{SO}_{4} \\
\left(\mathrm{NH}_{4}\right)_{2} \mathrm{SO}_{4}\end{array}$ & $\begin{array}{l}\text { ND } \\
0 \cdot 18 \\
0 \cdot 07\end{array}$ & $\begin{array}{l}0.88 \\
0.95 \\
0 \cdot 32\end{array}$ & $\begin{array}{l}0 \cdot 06 \\
0 \cdot 27 \\
0 \cdot 45\end{array}$ & $\begin{array}{l}0.90 \\
0.77 \\
0.29\end{array}$ \\
\hline
\end{tabular}

ND, Not detected.

\section{Effect of pyruvate accumulation on glutaminase B activity}

When the wild type strain was incubated statically (microaerophilic conditions) the pyruvate pool was larger than that found under aerated conditions (Table 3); this difference was not found in the pools of glyoxylate and 2-oxoglutarate (data not shown). Glutaminase activity was not detected in microaerophilic conditions when the in vivo assay was used; with the in vitro assay, the activity measured corresponded to $35 \%$ of that detected in extracts obtained from agitated cultures (Table 3). The low activity in extracts from static cultures could be attributable to the high intracellular pool of pyruvate which was found in this condition. The observed activity of a mixture of extracts obtained from agitated and static cultures represented only $40 \%$ of the expected value. These results correlate with the inhibitory effect of pyruvate described above (Fig. 2).

\section{Accumulation of glutamine and glutamate in the wild-type strain and mutant CN10}

Since an impairment in utilization of glutamine should result in its accumulation, we measured the intracellular pool of glutamine in the wild-type and mutant CN10 (Table 4). The mutant accumulated much more glutamine than the wild-type strain when the cells were incubated with glutamine or glutamine plus ammonium. It is worth noting that glutamine was undetectable in the wild-type strain when grown with this amino acid as sole nitrogen source. This could be due to the rapid utilization of the glutamine, since a glutamine pool was found at earlier periods of incubation (data not shown). With ammonium as nitrogen source the glutamine pool in mutant CN10 was nearly threefold lower than that found when this strain was grown on glutamine (Table 4). These data indicate that there is an inverse relation between the capacity of mutant CN10 to grow on different nitrogen sources (Fig. 1) and the intracellular pools of glutamine that this strain is able to accumulate (Table 4). 
Table 5. Glutaminase activity in cell extracts and detergent-treated pellets from strain $S 288 C$ and mutant $\mathrm{CN} 10$

Cells were grown on $\mathrm{MM}$ for $12 \mathrm{~h}$ with $0 \cdot 1 \%(\mathrm{w} / \mathrm{v})$ glutamine as nitrogen source. Pellets were solubilized with the extraction buffer, at $\mathrm{pH} 7 \cdot 5$, containing $0 \cdot 1 \%(\mathrm{w} / \mathrm{v})$ Triton $\mathrm{X}-100$.

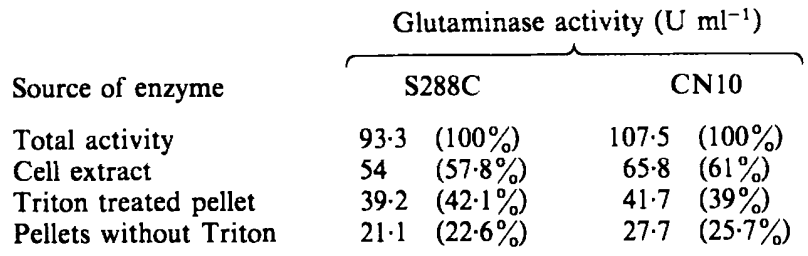

Table 6. Effect of pyruvate and heat treatment on glutaminase $A$ and $B$ activity in strain $S 288 C$ and mutant $C N 10$

Cells were grown on $\mathrm{MM}$ with $0.1 \%(\mathrm{w} / \mathrm{v})$ glutamine as nitrogen source. Pellets were solubilized with $0 \cdot 1 \%(w / v)$ Triton X-100.

\begin{tabular}{|c|c|c|c|c|}
\hline \multirow[b]{2}{*}{ Treatment } & \multicolumn{2}{|c|}{$\begin{array}{l}\text { Membrane-bound } \\
\text { glutaminase } \\
\left(\mathrm{pH} \mathrm{7.5)}\left(\mathrm{U} \mathrm{ml}^{-1}\right)\right.\end{array}$} & \multicolumn{2}{|c|}{$\begin{array}{c}\text { Soluble } \\
\text { glutaminase } \\
(\mathrm{pH} 8 \cdot 1)\left(\mathrm{U} \mathrm{ml}^{-1}\right)\end{array}$} \\
\hline & S288C & CN10 & S288C & $\mathrm{CN} 10$ \\
\hline None & $124 \cdot 16$ & $109 \cdot 54$ & $237 \cdot 44$ & $290 \cdot 20$ \\
\hline Pyruvate (60 mM) & $138 \cdot 30$ & $109 \cdot 78$ & $179 \cdot 44$ & $228.08^{*}$ \\
\hline Heat $\left(15 \mathrm{~min}\right.$ at $\left.60^{\circ} \mathrm{C}\right)$ & $130 \cdot 44$ & $124 \cdot 25$ & $169 \cdot 40$ & 163.93 \\
\hline
\end{tabular}

* Data obtained with 40 mm-pyruvate.

Although the mutation in strain $\mathrm{CN} 10$ only affected glutaminase $\mathrm{B}$, we measured the intracellular pools of glutamate found in the wild-type and mutant strains in order to determine the effect of this alteration on the levels of this amino acid (Table 4). In the presence of glutamine, mutant CN10 accumulated 3- to 15-fold more glutamate than the wild-type strain. When the two strains were incubated on ammonium, the mutant accumulated glutamate, although the pool was smaller than that found in the wild-type strain. However, the difference in growth rate between the mutant and the wild-type grown on ammonium cannot be attributed to a glutamate requirement, since this difference persisted if glutamate was added to the medium (data not shown).These data suggest that even though mutant CN10 is altered in glutaminase B activity, glutamine can still be degraded, probably through glutaminase A activity. Furthermore, these results rule out the possibility that the lack of growth of the mutant on glutamine and on glutamine plus ammonium could be due to a glutamate requirement.

\section{Glutaminase $A$ is a membrane-bound enzyme}

Since mutant CN10 retained glutaminase A activity, we decided to determine whether this activity was membrane bound. Glutaminase A activity was measured in pellets obtained from extracts of cells from mutant $\mathrm{CN} 10$ and the wild-type strain grown on glutamine as nitrogen source (Table 5). In the wild-type strain, $57.8 \%$ of total glutaminase activity was found in the supernatant, and $42.1 \%$ in the Triton X-100 treated pellets. The activity found in the pellet depended upon the extraction with Triton X-100, although some enzyme $(22.6 \%)$ could be solubilized without detergent (Table 5). Similar results were obtained for the mutant strain (Table 5).

Thus the enzyme could be loosely attached to the membrane. To distinguish whether glutaminase A or B was solubilized with Triton X-100 we studied the effect of pyruvate on the membrane-bound and soluble fractions of glutaminase obtained from the wild-type strain (Table 6). Pyruvate had no inhibitory effect on the membrane-bound fraction, whereas it has a 
significant effect on the soluble fraction. We were also able to distinguish the two activities by the fact that the glutaminase B activity of both strains was more heat labile than the glutaminase A activity (Table 6).

\section{DISCUSSION}

S. cerevisiae has two glutaminase activities, which we have named glutaminases $\mathbf{A}$ and $\mathbf{B}$. These enzymes differ in their sensitivity towards pyruvate, and glutaminase $A$ is thermostable whereas glutaminase $B$ is heat labile. The two activities can also be distinguished by their $\mathrm{pH}$ optima, 7.5 for glutaminase A and 8.1 for glutaminase B, and by their cellular location, since glutaminase A appears to be membrane-bound, and glutaminase B cytoplasmic. Pyruvate, 2oxoglutarate and glyoxylate inhibit glutaminase B activity. We have isolated a mutant, CN10, whose glutaminase $B$ is more sensitive to pyruvate and 2-oxoglutarate than the wild-type enzyme; it is suggested that this higher sensitivity results in inactivation of this enzyme in vivo. The physiological relevance of this regulation could be related to the availability of carbon skeletons under different culture conditions. Under microaerophilic conditions, pyruvate accumulates and glutaminase activity is repressed; these data suggest that under these conditions an alternative route of glutamine utilization, using 2-oxo acids, like the $\omega$-amidase pathway (Calderón et al., 1985), could be functioning (Soberón \& González, 1987).

The role of glutaminase B can be inferred from the phenotype of mutant CN10, which has an alteration in this enzyme. Our data indicate that glutaminase B plays a key role in the regulation of the intracellular pool of glutamine, since the mutant accumulates a large amount of this amino acid, even with ammonium as sole nitrogen source.

It appears that glutaminase A is membrane bound, although we do not know its intracellular location. This suggests the possibility of different physiological roles for the two glutaminase activities. If glutaminase $A$ is bound to the cell membrane it could deal mainly with the degradation of exogenous glutamine, while glutaminase B, being cytoplasmic, could regulate the levels of endogenous glutamine. This would result in a more efficient control of the intracellular glutamine pool.

Finally, our data indicate that the lack of growth of mutant CN10 on glutamine, or glutamine plus ammonium, is not due to a lack of glutamate; however, there is an inverse relation between the capacity to grow on different nitrogen sources and the intracellular glutamine content of this strain.

The authors are grateful to Lorenzo Segovia and David Romero for their critical review of the manuscript, to Jaime Mora for his enthusiasm and criticism throughout this work, to Gisela Du Pont for skilful technical assistance and to Ma. Estela Luna Gordoa for secretarial assistance.

The work was supported in part by a grant from Fondo de Estudios e Investigaciones Ricardo J. Zevada.

\section{REFERENCES}

Averman, T. L., Generalova, T. G., Polotskaya, I. V. \& Polotskil, M. A. (1981). Determination of glutaminase activity in yeast. Applied Biochemistry and Microbiology 17, 119-121.

BERGMEYER, M. J. (1963). Methods of Enzymatic Analysis, pp. 253-259. New York \& London: Academic Press.

Calderón, J., Morett, E. \& Mora, J. (1985). $\omega$ Amidase pathway in the degradation of glutamine in Neurospora crassa. Journal of Bacteriology 161, 807809.

COOK, W. R., Hoffman, J. H. \& Bernlohr, R. W. (1981). Occurrence of an inducible glutaminase in Bacillus licheniformis. Journal of Bacteriology 148, 365-367.
Dubois, E., Vissers, S., Grenson, M. \& Wiame, J. M. (1977). Glutamine and ammonia in nitrogen catabolite repression of Saccharomyces cerevisiae. Biochemical and Biophysical Research Communications 75, 233-239.

FINK, G. R. (1970). The biochemical genetics of yeast. Methods in Enzymology 16, 58-78.

González, A., Rodríguez, L., Olivera, H. \& SOBERón, M. (1985). NADP+-dependent glutamate dehydrogenase activity is impaired in mutants of Saccharomyces cerevisiae that lack aconitase. Journal of General Microbiology 131, 2565-2571.

Hartman, S. C. (1968). Glutaminase of Escherichia coli. I. Purification and general catalytic properties. Journal of Biological Chemistry 243, 853-863. 
Kang, L., Keeler, M., Dunlop, P. C. \& Roon, R. J. (1982). Nitrogen catabolite repression in a glutamate auxotroph of Saccharomyces cerevisiae. Journal of Bacteriology 151, 29-35.

Legrain, C., Vissers, S., Dubois, E., Legrain, M. \& Wiame, J. M. (1982). Regulation of glutamine synthetase from Saccharomyces cerevisiae by repression, inactivation and proteolysis. European Journal of Biochemistry 123, 611-616.

Monod, J., Wyman, J. \& ChangeuX, J. P. (1965). On the nature of allosteric transitions: a plausible model. Journal of Molecular Biology 12, 88-118.
Nimmo, G. A. \& Tipton, K. F. (1981). Time-dependent activation and inactivation of pig brain glutaminase. Biochemical Pharmacology 30, 1635-1641.

Polaina, J. A. \& CONDE, J. (1981). Use of the polyene antibiotic $\mathrm{N}$-glycosyl-polifungin in counterselecting yeast mutants. Mutation Research 91, 111-114.

SOBERón, M. \& GonZÁlez, A. (1987). Glutamine degradation through the $\omega$-amidase pathway in Saccharomyces cerevisiae. Journal of General Microbiology 133, 9-14. 